\title{
Absence of autoimmunity to type II collagen in generalised nodal osteoarthritis
}

\author{
R B Clague, K Morgan, I Collins, M Pattrick, M Doherty
}

\begin{abstract}
A cardinal feature of generalised nodal osteoarthritis is the loss of articular cartilage. To determine if autoimmunity to these cartilage collagens occurred, serum antibodies to native and denatured type II collagen were measured by enzyme linked immunosorbent assay (ELISA) in 96 patients ( 90 women, six men, aged 47-91 years) with generalised nodal osteoarthritis. Generalised nodal osteoarthritis was diagnosed by typical clinical and radiological features. Serum samples from 42 blood donors were assayed as controls. No significant difference was found between the patients with generalised nodal osteoarthritis and the controls. Furthermore, the 20 patients who were HLA-A1, B8 positive had similar antibody levels to the group as a whole. One woman patient with generalised nodal osteoarthritis (HLA-A1, B8 negative) had markedly increased antibody levels to native and denatured type II collagen in a pattern similar to that seen in patients with rheumatoid arthritis. This patient did not develop super added rheumatoid arthritis during a three year follow up period. Autoimmunity to type II collagen is therefore rare in generalised nodal osteoarthritis. A lack of collagen antibodies in a condition characterised by hyaline cartilage loss suggests that the presence of such antibodies in rheumatoid arthritis is more than a secondary event to joint damage.
\end{abstract}

Generalised nodal osteoarthritis is well established as a subset of osteoarthritis and is characterised by polyarticular interphalangeal and thumb base involvement with the formation of Heberden (and Bouchard) nodes. ${ }^{1}$ Its aetiopathogenesis is unknown, but because of its marked predominance in women, frequent perimenopausal onset, and increased incidence of the histocompatibility antigens (HLA) Al, B8, it has been suggested that an autoimmune diathesis to a normal joint component may occur. ${ }^{2}$ This is further supported by the histology of the synovium, which may resemble rheumatoid arthritis, ${ }^{3}$ and an increased prevalence of rheumatoid factor reported in one early study. ${ }^{4}$

Autoantibodies to the major cartilage collagen, type II, have been found in serum samples from some patients with rheumatoid arthritis, and may be involved in its pathogenesis. ${ }^{5} \mathrm{~A}$ cardinal feature of generalised nodal osteoarthritis is the loss of articular cartilage with the release of type II collagen. For this reason we investigated the incidence of serum autoantibodies to native and denatured type II collagen in patients with this disease.

\section{Patients and methods}

PATIENTS

Serum samples were available from 96 (90 women, six men) unrelated patients born in the United Kingdom with typical clinical and radiographic features of symptomatic generalised nodal osteoarthritis. These patients were attending the rheumatology unit at the City Hospital, Nottingham and have been described previously. ${ }^{2}$ Their ages ranged from 47 to 91 years (mean 67 years). Forty two serum samples from normal blood donors were used as controls. Aliquots of serum samples were stored at $-20^{\circ} \mathrm{C}$ until required.

\section{COLLAGENS}

Bovine type II collagen was extracted from bovine nasal septa by pepsin digestion and was extensively purified by differential salt precipitation and dialysis against phosphate buffers. ${ }^{6}$ The lyophilised collagen was stored at $-20^{\circ} \mathrm{C}$ until required. The collagen was checked for purity by sodium dodecyl sulphate/polyacrylamide gel electrophoresis and by immunoblotting with specific antisera. No uronic acid could be detected by the method of Bitter and Muir, ${ }^{7}$ indicating that there was no proteoglycan contamination. The collagen was dissolved at a concentration of $2 \mathrm{mg} / \mathrm{ml}$ in $0.45 \mathrm{M}$ sodium chloride/0.02 M TRIS buffer (pH 7.5) before use.

DETECTION OF ANTICOLLAGEN ANTIBODIES BY ENZYME LINKED IMMUNOSORBENT ASSAY (ELISA) Serum samples were tested at a dilution of $1 / 100$ for anticollagen antibodies in a solid phase double antibody ELISA as previously described. ${ }^{6}$ Samples, controls, and known positive standards (patients with rheumatoid arthritis) were screened in one assay using alkaline phosphatase labelled antihuman IgGAM (Dako) as the second antibody. The results were expressed in arbitrary units.

\section{HLA TISSUE TYPING}

HLA-A and B antigens were determined in 93 patients by standard lymphocytotoxic techniques. $^{8}$ 
Poisson like distribution. The analysis was therefore repeated using the square roots of the observed antibody levels. ${ }^{9}$ The levels of variation associated with the means were determined by detransformation and are represented by $99 \%$ confidence limits. The differences between the study groups were tested using an $\mathrm{F}$ ratio from a standard analysis of variance table with the GLIM 3.77 statistical computer program. ${ }^{10}$

\section{Results}

Table 1 shows the results of determining antibodies to native and denatured type II collagen in the controls and patients with generalised nodal osteoarthritis. There was no significant difference in the results obtained in each of these groups ( $p>0.05)$. Table 2 shows that there was also a lack of correlation between the level of antibodies to native and denatured type II collagen and the presence or absence of HLA-A1, B8 ( $p>0.05)$ in the group of patients with generalised nodal osteoarthritis.

One patient had levels of serum antibodies to native type II collagen (765 units) well above the normal upper limit (134 units). The same patient also had more than the normal upper limit (794 units) of serum antibodies to denatured type II collagen (1315 units). This patient also had increased levels of antibodies to native type V, VI, and XI collagens (minor cartilage collagens) in her serum samples (data not shown). She therefore seemed to be reacting to several collagens found in the joint, not just to type II collagen. None of the serum samples from blood donors had increased levels of antibodies to native or denatured type II collagen, nor to the minor cartilage collagens.

The patient with generalised nodal osteoarthritis with increased antibody levels was HLA-A2, B12 44, B15 positive with an $\alpha_{1}$

Table 1 Presence of serum antibodies to native and denatured type II collagen (units) in 96 patients with generalised nodal osteoarthritis and 42 controls

\begin{tabular}{|c|c|c|c|c|}
\hline & \multicolumn{2}{|c|}{$\begin{array}{l}\text { Native type II } \\
\text { collagen }\end{array}$} & \multicolumn{2}{|c|}{$\begin{array}{l}\text { Denatured type II } \\
\text { collagen }\end{array}$} \\
\hline & Controls & $\begin{array}{l}\text { Generalised nodal } \\
\text { osteoarthritis }\end{array}$ & Controls & $\begin{array}{l}\text { Generalised nodal } \\
\text { osteoarthritis }\end{array}$ \\
\hline $\begin{array}{l}\text { Positive } \\
\text { Ranget } \\
\text { Mean }\end{array}$ & $\begin{array}{l}0 \\
42^{0-103}\end{array}$ & $\begin{array}{l}1^{*}(1 \%) \\
5-765 \\
42\end{array}$ & $\begin{array}{l}0 \\
7-674 \\
180\end{array}$ & $\begin{array}{l}1^{*}(1 \%) \\
213-1315\end{array}$ \\
\hline
\end{tabular}

${ }^{*}$ Number of sera above the $99 \%$ confidence limits of controls (native type II >134 units; denatured II $>794$ units).

tRange of values obtained for the serum samples in each group.

Table 2 Range and correlation between presence or absence of $H L A-A 1, B 8$ antigens and antibodies to type II collagen (units) in patients with generalised nodal osteoarthritis. Values given are range (mean)

\begin{tabular}{|c|c|c|}
\hline & $\begin{array}{l}\text { HLA-A1, B8 } \\
\text { positive } \\
(\mathrm{n}=20)\end{array}$ & $\begin{array}{l}\text { HLA-Al, B8 } \\
\text { negative } \\
(\mathrm{n}=73)\end{array}$ \\
\hline $\begin{array}{l}\text { Native type } \\
\text { II collagen } \\
\text { Denatured type }\end{array}$ & $17-85(42)^{*}$ & $5-765(42)^{*}$ \\
\hline II collagen & $62-517(225) \dagger$ & $17-1315(210) \dagger$ \\
\hline
\end{tabular}

antitrypsin phenotype of $M$ at a normal concentration. She was negative for rheumatoid factor with no clinical or radiographic features to distinguish her from the other patients. This patient had not developed superadded rheumatoid arthritis during a three year follow up period.

\section{Discussion}

Only one patient out of 96 with generalised nodal osteoarthritis had serum antibodies to native and denatured type II collagen, which indicates that autoimmunity to this cartilage collagen is rare, despite the loss of articular cartilage. This contrasts with a previous study of 94 patients with large joint osteoarthrosis, in which 67 patients $(71 \%)$ had serum antibodies to type II collagen. ${ }^{11}$ However, that study used the passive haemagglutination technique, which has an inherent susceptibility to many anomalous reactions ${ }^{12}$ and a lack of specificity for type II collagen was seen in the results. The negative results in generalised nodal osteoarthritis reported here compare with an incidence of $10 \%$ for antibodies to native type II collagen and $25 \%$ for antibodies to denatured type II collagen in patients with rheumatoid arthritis. ${ }^{6}$ Furthermore, antibody levels to type II collagen in generalised nodal osteoarthritis serum samples were no higher in patients possessing the socalled autoimmune genes (HLA-Al, B8). This finding contrasts with that in rheumatoid arthritis where we have previously shown that HLA$\mathrm{A1}, \mathrm{B} 8, \mathrm{DR} 3$ is associated with higher levels of serum antibodies to native type II collagen. ${ }^{13}$ These findings suggest that the release of native and denatured type II collagen from degenerating articular cartilage fails to stimulate autoimmunity in generalised nodal osteoarthritis. Thus the release of these autoantigens into the joint is not a sufficient stimulus for the production of autoantibodies to type II collagen, and suggests that the presence of such autoantibodies in rheumatoid arthritis is more than just a secondary event to joint damage.

The one patient with generalised nodal osteoarthritis who had antibodies to native and denatured type II collagen was HLA-A1, B8 negative. She also had high levels of antibodies to the minor cartilage collagens; these antibodies are only rarely found in patients with rheumatoid arthritis. ${ }^{6}$ It is possible that her antibodies may be directed against different epitopes on the collagen molecules than the autoantibody found in rheumatoid arthritis patients, and so may not be pathogenic. ${ }^{14} \mathrm{We}$ hope to investigate this and will also follow her progress to determine whether she develops rheumatoid arthritis.

The presence of serum antibodies to type II collagen is therefore not a generalised feature in generalised nodal osteoarthritis, although our study has not ruled out the possible role of local autoantibody production and fixation within the joint. Such immune complexes have been demonstrated in articular collagenous joint tissues in $51 \%$ of patients with idiopathic osteoarthritis. ${ }^{15}$ An investigation of autoimmunity to other cartilaginous antigens such as proteoglycans would be of interest. 
We thank the Arthritis and Rheumatism Council, the Bingham Trust, Buxton, and the University of Nottingham Medical Schoo for financial support. Mr E B Faragher is thanked for statistica advice and analysis, and Miss Diane Oliver for secretarial assistance.

1 Mankin H J. Clinical features of osteoarthritis. In: Kelly W N, Harris E D, Ruddy S, Sledge C B, eds. Textbook of rheumatology. 3rd ed. Philadelphia: Saunders, 1989:1480-500.

2 Pattrick M, Manhire A, Ward A M, Doherty M. HLA-A, B antigens and $\alpha_{1}$ antitrypsin phenotypes in nodal generalised antigens and $\alpha_{1}$ antitrypsin phenotypes in nodal generalised
osteoarthritis and erosive osteoarthritis. Ann Rheum Dis osteoarthritis and

3 Revell P A, Mayston V, Lalor P, Mapp P. The synovial membrane in osteoarthritis: a histological study including the characterisation of the cellular infiltrate present in inflammatory osteoarthritis using monoclonal antibodies. Ann Rheum Dis 1988; 47: 300-7.

4 Kellgren J H, Moore R. Generalised osteoarthritis and Heberden's nodes. BMF 1952; i: $181-4$

5 Clague R B. Autoantibodies to cartilage collagens in rheumatoid arthritis. Do they perpetuate the disease or are they irrelevant? Br $\mathcal{F}$ Rheumatol 1989; 28: 1-6.

6 Morgan K, Clague R B, Collins I, Ayad S, Phinn S, Holt P J L. Incidence of antibodies to native and denatured cartilage collagens (types II, IX and XI) and to type I collagen in rheumatoid arthritis. Ann Rheum Dis 1987; 46: 902-7.

7 Bitter T, Muir H M. A modified uronic acid carbazole reaction. Anal Biochem 1962; 4: 330-4.

8 Welsh K I, Batchelor J R. Assays for antibodies against histocompatibility antigens. In: Weir D M, ed. Handbook of experimental immunology. Oxford: Blackwell Scientific, 1978: 35.1-20.

9 Box G E P, Cox D R. An analysis of transformations. Fournal of the Royal Statistical Society B 1964; 26: 211-52.

10 Baker R J. GLIM 3.77 Reference manual. Oxford: Numerical Algorithms Group, 1985.

11 Novotna J, Adam M. Anticollagen antibodies in patients with osteoarthritis. Connective Tissue Disease 1986; 5: 3-12.

12 Beard H K, Lea D J, Ryvar R. Anomalous reactions in the haemagglutination assay for anticollagen antibodies, studies haemagglutination assay for anticollagen antibodies, studies on patients with rheumatoid arthritis and chrom
pain. F Immunol Methods 1979; 31: 119-28.

pain. F Immunol Methods 1979; 31: 119-28.
13 Klimiuk P S, Clague R B, Grennan D M, Dyer P A, Smeaton I, Harris R. Autoimmunity to native type II collagen-a distinct genetic subset of rheumatoid arthritis. $\mathcal{F}$ Rheumato 1985; 12: 865-70.

14 Morgan K. What do anti-collagen antibodies mean? Ann Rheum Dis 1990; 49: 62-5.

15 Cooke T D V, Bennett E L, Ohno O. The deposition of immunoglobulins and complement components in osteoarthritic cartilage. Int Orthop 1980; 4: 211-7. 